\title{
Effects on sister chromatid exchange frequency of polymorphisms in DNA repair gene XRCC1 in smokers
}

\author{
Yu-Chen Lei ${ }^{a}$, Shing-Jen Hwang ${ }^{a}$, Chuen-Chau Chang ${ }^{a}$, Hsen-Wen Kuo ${ }^{b}$, \\ Jiin-Chyuan Luo ${ }^{c}$, Ming J.W. Chang ${ }^{\mathrm{c}}$, Tsun-Jen Cheng ${ }^{\mathrm{a}, *}$ \\ a Institute of Occupational Medicine and Industrial Hygiene, College of Public Health, National Taiwan University, \\ No. 1 Ren-Ai Road, Sec. 1, 10018 Taipei, Taiwan, ROC \\ ${ }^{\mathrm{b}}$ Institute of Environmental Health, China Medical College, Taichung, Taiwan, ROC \\ ${ }^{\mathrm{c}}$ College of Medicine, Chang Gung University, Taoyuan, Taiwan, ROC
}

Received 2 November 2001; accepted in revised form 17 May 2002

\begin{abstract}
The association between metabolic polymorphisms and cigarette smoking-induced cancers has been documented. However, the role of DNA repair polymorphism in carcinogenesis is less clear. To investigate if the polymorphisms of metabolic traits and DNA repair modulate smoking-related DNA damage, we used sister chromatid exchange (SCE) as a marker of genetic damage to explore the relationship of microsomal epoxide hydrolase (mEH), glutathione $S$-transferase M1 (GSTM1), and $\mathrm{X}$-ray cross-complementing group 1 (XRCC1) and cigarette smoking-induced SCE. Sixty-one workers without significant exposure to mutagens were recruited. Questionnaires were completed to obtain detailed occupational, smoking, and medical histories. SCE frequency in peripheral lymphocytes was determined using a standard cytogenetic assay and GSTM1, mEH (exons 3 and 4), XRCC1 (codon 399) genotypes were determined using polymerase chain reaction-restriction fragment length polymorphism (PCR/RFLP). Smokers had higher SCE frequency than non-smokers $(8.4$ versus $7.1, P<0.05$ ). Among workers who had smoked equal to or greater than 10 cigarettes each day, those with XRCC1 Arg/Gln + Gln/Gln had higher SCE frequency than those with XRCC1 Arg/Arg after adjusting for potential confounders $(9.0$ versus $7.9, P<0.05)$. The interaction of XRCC1 and cigarettes smoked per day on SCE frequency was also observed $(P=0.02)$. There was no significant interaction between cigarettes smoked per day with GSTM1 and mEH on SCE frequency. Our results support previous epidemiological studies that XRCC1 may play a role in cigarette smoking-induced lung cancer.
\end{abstract}

(C) 2002 Elsevier Science B.V. All rights reserved.

Keywords: Microsomal epoxide hydrolase; X-ray cross-complementing group 1; Glutathione $S$-transferase M1; Sister chromatid exchange; Cigarette smoking; Polymorphism; DNA repair; Metabolism

Abbreviations: $\mathrm{mEH}$, microsomal epoxide hydrolase; XRCC1, $\mathrm{X}$-ray cross-complementing group 1; SCE, sister chromatid exchange; GSTM1, glutathione $S$-transferase M1

* Corresponding author. Tel.: +886-2-23957845; fax: +886-2-23957845.

E-mail address: tcheng@ha.mc.ntu.edu.tw (T.J. Cheng).

\section{Introduction}

Cigarette smoking is the major cause of lung cancer and is associated with risks for cancers of the larynx, oral cavity, and urinary bladder [1]. There are more than 3000 compounds including 30 carcinogens in cigarette smoke, such as polycyclic aromatic hydrogens, aromatic amines, and tobacco-specific 
nitrosamine [1]. However, the exact mechanism of carcinogenesis caused by cigarette smoke remains unclear. Results of previous studies have suggested that genetic susceptibility to cigarette smoke-induced cancers may result from the polymorphisms in carcinogen metabolism [2,3] and DNA repair [4,5]. Thus, individuals with inherited variant metabolic enzyme activities and repair capacities might have altered risks of cigarette smoke-induced DNA damage [6,7].

Epidemiological studies have indicated that several important metabolic traits can modulate the risk of cigarette smoke-induced lung cancers, including CYP1A1, CYP2D6 and glutathione $S$-transferase M1 (GSTM1) [8-10]. In addition to lung cancer, GSTM1 was reported to be associated with the risk of cigarette-related cancers, including cancers of the larynx and bladder [11]. Moreover, the association between cigarette smoke-induced DNA damage and metabolic genes has also been observed. The modulation of benzo(a)pyrene DNA adduct levels by CYP1A1 and GSTM1 have been reported [12]. In addition, GSTM1 was associated with sister chromatid exchange (SCE) frequency [6] . Although, the association of polymorphism in metabolic genes with cigarette smoke-induced damage has been widely studied, limited data are available that address the role of microsomal epoxide hydrolase $(\mathrm{mEH})$ in cigaretterelated carcinogenesis.

Microsomal epoxide hydrolase is an enzyme involved in the detoxification and activation of highly reactive epoxide intermediates, including benzo(a)pyrene and other xenobiotics [13], and may play an important role in carcinogenesis. Two polymorphisms in exons 3 and 4 of $\mathrm{mEH}$ have been identified $[14,15]$. One variant is characterized by the substitution of histidine for tyrosine at position 113 in exon 3 (Tyr113 $\rightarrow$ His113); another polymorphism in exon 4 results in substitution of arginine for histidine at position 139 (His139 $\rightarrow$ Arg139). In a study by Smith and Harrison [16], they observed that individuals with slow $\mathrm{mEH}$ activity may be more susceptible to COPD and emphysema. The association between $\mathrm{mEH}$ and lung cancer has also been reported recently [17]. However, the relationship between DNA damage and $\mathrm{mEH}$ in smokers was limited.In addition to metabolic traits, DNA repair capacity also plays an important role in smoking-related carcinogenesis [18]. Consequently, DNA repair gene polymorphisms, which may alter the function of efficiency of DNA repair, may contribute to cancer susceptibility [18]. X-ray cross-complementing group 1 (XRCC1), a DNA repair protein involved in single-strand breaks and base excision repair (BER) pathway, has been reported to be responsible for the efficient repair of DNA damage caused by active oxygen, ionization, and alkylating agents [19]. Three polymorphisms of DNA repair genes XRCC1 have been identified at codon 194 (Arg to Trp), 280 (Arg to His), and 399 (Arg to Gln) [20]. In particular, XRCC1 Gln399 polymorphism resulting in single base substitution, which may affect binding with PARP (poly(ADP-ribose) polymerase), may lead to deficiency of DNA repair [21]. In cells lacking XRCC1 activity, an increased SCE frequency has been observed [22]. In addition, defects in XRCC1 Gln399 have been reported to be associated with increased smoking-related cancers, including head and neck, and lung cancers [5,23]. However, Stern et al. [4] reported a possible reduction in bladder cancer risk among subjects with XRCC1 Gln399 allele. A recent study by Duell et al. [7] revealed that individuals with Gln399 allele might be at greater risk for tobacco-related DNA damage. It appears that the association between XRCC1 and cigarette smoke-induced carciniogenesis is not consistent. To further investigate the role of XRCC1 in smoking-related carcinogenesis, we used SCE frequency in peripheral lymphocytes, a commonly used marker for DNA damage, to determine the association of XRCC1 genotypes with cigarette smoking-induced DNA damage.

\section{Materials and methods}

\subsection{Study population}

A total of 61 subjects were selected into our current study from 85 male workers recruited from a resin synthesis plant, which has been earlier described [24]. Information of smoking history, medical history and occupational exposure were gathered from interviewadministered questionnaires. Smokers were defined as those who had been smoking within 1 month of blood collection. Alcohol drinking greater than once each week was defined as habitual alcohol drinking. Among smokers in the previous study population, nine subjects exposed to ECH greater than $1 \mathrm{ppm}$ had mean 
SCE frequency of 9.3, 19 subjects exposed to ECH less than $1 \mathrm{ppm}$ had mean SCE frequency of 8.3, and 14 non-exposed subjects had mean SCE frequency of 8.1. Among non-smokers, 12 subjects exposed to ECH greater than $1 \mathrm{ppm}$ had mean SCE frequency of 7.6, 16 subjects exposed to ECH less than $1 \mathrm{ppm}$ had mean SCE frequency of 7.1, and 15 non-exposed subjects had mean SCE frequency of 7.2. To explore the effects of genotypes on SCE in smokers, we excluded 21 subjects with known ECH exposure greater than $1 \mathrm{ppm}$. Thirty-five workers with ECH exposure less than $1 \mathrm{ppm}$ and 29 non-exposed subjects were included for this study. Three subjects were further excluded as a result of incomplete questionnaire of smoking information, thus, 61 subjects were included in the analysis.

\subsection{SCE assay}

The SCE in peripheral lymphocytes was performed according to a standard cytogenetic method [6]. Briefly, $1 \mathrm{ml}$ of whole blood was added to $9 \mathrm{ml}$ of culture medium with phytohemagglutinin, and the mixture was maintained at $37.5^{\circ} \mathrm{C}$ in $5 \% \mathrm{CO}_{2}$ for $72 \mathrm{~h}$. Fifty micromolar 5-bromodeoxyuridine was added to the culture at $24 \mathrm{~h}$ to achieve differential staining. The lymphocytes were harvested with hypotonic $\mathrm{KCl}$ solution and fixed in methanol:acetic acid $(3: 1, \mathrm{v} / \mathrm{v})$. The chromosomes were stained using a modification of the fluorescence-plus Giemsa technique by Perry and Wolff [25]. For each subject, 50 cells at metaphase were scored to determine the individual SCE frequency. All slides were scored by one reader who was blind to the status of the subjects.

\subsection{Genotyping of XRCC1 codon 399}

XRCC1 polymorphism was determined using PCR-RFLP assay [7]. Primers used for exon 10 (codon 399) were 5'-CCCCAAGTACAGCCAGGTC-3' and 5'-TGTCCCGCTCCTCTCAGTAG-3'. The amplifications were carried out with denaturation at $95^{\circ} \mathrm{C}$ for $30 \mathrm{~s}$, annealing at $60^{\circ} \mathrm{C}$ for $30 \mathrm{~s}$, and extension at $72{ }^{\circ} \mathrm{C}$ for $30 \mathrm{~s}$. PCR products were digested with MspI at $37^{\circ} \mathrm{C}$ overnight and analyzed on $2 \%$ agarose gel. Arg/Arg individuals had 94 and 148 bp fragments, Arg/Gln individuals had 94, 148 and 242 bp fragments, and Gln/Gln individuals had only $242 \mathrm{bp}$ fragments.

\subsection{Genotyping of $m E H$}

The primers used for $\mathrm{mEH}$ (exon 3 ) were $5^{\prime}$-GATCGATAAGTTCCGTTTCACC-3' , and 5'-ATCCTTAGTCTTGAAGTGAGGAT-3' [16]. Thirty-five cycles of amplification were performed with denaturation at $95^{\circ} \mathrm{C}$ for $1 \mathrm{~min}$, annealing at $55^{\circ} \mathrm{C}$ for $60 \mathrm{~s}$, and extention at $73^{\circ} \mathrm{C}$ for $60 \mathrm{~s}$. PCR products were digested with EcoRV at $37^{\circ} \mathrm{C}$ for $8 \mathrm{~h}$ and resolved in $2 \%$ agarose gel. The wild type had only $162 \mathrm{bp}$ fragments, heterozygous variants had 162, 140 and $22 \mathrm{bp}$ fragments, and homozygous variants had 140 and $22 \mathrm{bp}$ fragments. The primer used for $\mathrm{mEH}$ (exon 4) were 5'-ACATCCACTTCATCCACGT-3' and 5'-ATGCCTbreak CTGAGAAGCCAT-3'. Amplifications were performed with denaturation at $94^{\circ} \mathrm{C}$ for $30 \mathrm{~s}$, annealing at $56^{\circ} \mathrm{C}$ for $20 \mathrm{~s}$, and extension at $72^{\circ} \mathrm{C}$ for $20 \mathrm{~s}$. The PCR products were digested with RsaI at $37^{\circ} \mathrm{C}$ overnight and analyzed on $2 \%$ agarose gel. The wild type had a $210 \mathrm{bp}$ fragment, homozygous variant had 164 and $46 \mathrm{bp}$ fragments, and heterozygous variant had all three fragments.

\subsection{Genotyping of GSTM1}

The assay for GSTM1 genotyping has been described earlier [24]. Briefly, the primers used for the GSTM1 gene were 5'-CTGCCCTACTTGATTGATGGG- $3^{\prime}$ and $5^{\prime}$-CTGGATTGTAGCAGATCATGC- $3^{\prime}$. The human $\beta$-globin gene (110 bp) was also amplified in each reaction as a positive control to confirm the presence of amplifiable DNA in the samples. The primers used for $\beta$-globin were $5^{\prime}$-ACACAACTGTGTTCACTAGC- $3^{\prime}$ and 5'-CAACTCATCCACGTTCACC-3'. The amplifications were carried out with denaturation at $94^{\circ} \mathrm{C}$ for $1 \mathrm{~min} 30 \mathrm{~s}$, annealing at $52{ }^{\circ} \mathrm{C}$ for $1 \mathrm{~min}$, and extension at $65^{\circ} \mathrm{C}$ for $1 \mathrm{~min}$. The reaction products were then resolved using electrophoresis in $2 \%$ agarose gels. Individuals with one or more GSTM1 alleles had $273 \mathrm{bp}$ fragments.

\subsection{Statistical analysis}

The SAS 6.11 software was used for data analyses. ANOVA was used to test the differences on SCE frequency by smoking status, and genotypes. SCE frequency was further compared using stratified analysis by smoking (non-smokers, cigarette smoked 
per day $<10$, and cigarette smoked per day $\geq 10$ ) and various genotypes XRCC1, GSTM1, mEH (exons 3 and 4) after adjusting for potential confounders. Interaction term of cigarettes smoked per day and genotypes was also assessed in the general linear model (GLM).

\section{Results}

Demographic characteristics and the genotype prevalence of study subjects are summarized in Table 1. The mean age of the subjects was $32.4 \pm 5.2$ (S.D.) years. Sixty-one subjects had mean SCE frequency of $7.8 \pm 1.2$. Smokers had higher SCE frequency than non-smokers (8.4 versus 7.1, respectively; $P<0.05$ ). Twenty-seven (44.3\%) subjects had GSTM1 functional alleles, $35(57.3 \%)$ had at least one mutation site in $\mathrm{mEH}$ (exon 3 ) and $13(21.3 \%$ ) had one or more mutation site in $\mathrm{mEH}$ (exon 4). XRCC1 codon 399 $\mathrm{Arg} / \mathrm{Gln}+\mathrm{Gln} / \mathrm{Gln}$ variants was found in $47.5 \%$ of subjects.

Crude and adjusted mean SCE frequency for the joint effects of smoking and DNA repair gene XRCC1, and metabolic traits GSTM1 and mEH (exons 3 and 4) are shown in Table 2. Heterozygous and homozygous variants for each genotype were combined to increase sample size. Among smokers who had smoked greater than 10 cigarettes per day, mean SCE frequency in those with $\mathrm{Arg} / \mathrm{Gln}+\mathrm{Gln} / \mathrm{Gln}$ of XRCC1 was significantly higher than Arg/Arg carrier (9.0 versus 7.9, $P<0.05$ ), after adjusting for age, GSTM1, and $\mathrm{mEH}$ (exons 3 and 4). To investigate whether the polymorphism of XRCC1 codon 399 modulate the effect of cigarette smoking-induced SCE frequency, we evaluated interaction term between XRCC1 and smoking status (non-smoker, cigarette smoked per day < 10 , and cigarette smoked per day $\geq 10$ ). Significant interaction between XRCC1 polymorphisms and smoking were observed $(P=0.02)$. Among smokers who had smoked less than 10 cigarettes per day, subjects with GSTM1 null type had higher SCE frequency than those with GSTM1 non-null type (8.6 versus 7.8). However, the relationship did not reach a statistical significance. Similar but less prominent relationship between GSTM1 polymorphism was also observed among smokers who had smoked greater than 10 cigarettes per day and among non-smokers. After
Table 1

Demographic characteristics and prevalence of glutathione $S$-transferase M1, microsomal epoxide hydrolase, and X-ray cross-complementing group 1 among workers stratified by smoking status

\begin{tabular}{|c|c|c|c|}
\hline \multirow[t]{2}{*}{ Variables } & \multicolumn{3}{|c|}{ Smoking status } \\
\hline & No & Yes & All \\
\hline Number & 31 & 30 & 61 \\
\hline Mean SCE frequency & $7.1 \pm 1.2^{\mathrm{a}}$ & $8.4 \pm 1.0$ & $7.8 \pm 1.2$ \\
\hline $\begin{array}{l}\text { Smoking } \\
\text { Pack-years } \\
\text { Cigarette per day }\end{array}$ & $\begin{array}{l}0 \\
0\end{array}$ & $\begin{array}{r}8.2 \pm 5.1 \\
11.7 \pm 6.6\end{array}$ & \\
\hline $\begin{array}{l}\text { Age (year) } \\
\text { Duration of } \\
\text { employment (year) }\end{array}$ & $\begin{array}{r}32.5 \pm 5.3 \\
8.0 \pm 5.0\end{array}$ & $\begin{array}{r}32.2 \pm 5.1 \\
5.4 \pm 3.6\end{array}$ & $\begin{array}{r}32.4 \pm 5.2 \\
6.6 \pm 4.5\end{array}$ \\
\hline $\begin{array}{l}\text { Alcohol drinking } \\
\text { Yes } \\
\text { No }\end{array}$ & $\begin{array}{r}5(16.1 \%)^{\mathrm{b}} \\
26(83.9 \%)\end{array}$ & $\begin{array}{l}10(66.7 \%) \\
20(33.3 \%)\end{array}$ & $\begin{array}{l}15(25 \%) \\
46(75 \%)\end{array}$ \\
\hline $\begin{array}{l}\text { GST M1 } \\
\text { Null } \\
\text { Non-null }\end{array}$ & $\begin{array}{l}19(61.3 \%) \\
12(38.7 \%)\end{array}$ & $\begin{array}{l}15(50.0 \%) \\
15(50.0 \%)\end{array}$ & $\begin{array}{l}34(55.7 \%) \\
27(44.3 \%)\end{array}$ \\
\hline $\begin{array}{l}\mathrm{mEH}(\text { exon } 3) \\
\quad 1-1 \\
1-2 \\
2-2\end{array}$ & $\begin{array}{r}10(32.3 \%) \\
15(48.3 \%) \\
6(19.4 \%)\end{array}$ & $\begin{aligned} 16 & (53.3 \%) \\
7 & (23.3 \%) \\
7 & (23.3 \%)\end{aligned}$ & $\begin{array}{l}26(42.6 \%) \\
22(36.1 \%) \\
13(21.3 \%)\end{array}$ \\
\hline $\begin{array}{l}\text { mEH (exon 4) } \\
\quad 1-1 \\
1-2 \\
2-2\end{array}$ & $\begin{aligned} 24 & (77.4 \%) \\
6 & (19.3 \%) \\
1 & (3.3 \%)\end{aligned}$ & $\begin{array}{l}24(80.0 \%) \\
6(20.0 \%) \\
0\end{array}$ & $\begin{aligned} 48 & (78.7 \%) \\
12 & (19.7 \%) \\
1 & (1.6 \%)\end{aligned}$ \\
\hline $\begin{array}{l}\text { XRCC1 } \\
\text { Arg/Arg } \\
\text { Arg/Gln } \\
\text { Gln/Gln }\end{array}$ & $\begin{array}{c}16(51.6 \%) \\
14(45.2 \%) \\
1(3.2 \%)\end{array}$ & $\begin{aligned} 16 & (53.3 \%) \\
11 & (36.7 \%) \\
3 & (10 \%)\end{aligned}$ & $\begin{aligned} 32 & (52.5 \%) \\
25 & (40.9 \%) \\
4 & (6.6 \%)\end{aligned}$ \\
\hline
\end{tabular}

${ }^{a}$ Mean \pm S.D.

b Number (\%).

${ }^{c}$ Alcohol drinking was defined as drinking greater than once each week.

adjusting for age, XRCC1 and GSTM1, no significant association of $\mathrm{mEH}$ exons 3 and 4 with cigarette smoking-induced SCE was observed.

Further regression analysis between SCE frequency and cigarettes smoked per day indicated that XRCC1 $\mathrm{Arg} / \mathrm{Gln}+\mathrm{Gln} / \mathrm{Gln}$ genotypes had a significantly steeper slope as compared with the Arg/Arg carrier $(P<0.05$, Table 3$)$. The association between SCE and cigarette smoked per day with XRCC1 Arg/Gln + Gln/Gln variants and Arg/Arg carriers are presented in Fig. 1. A similar comparison of the 
Table 2

Crude and adjusted sister chromatid exchange frequency for the joint effect of smoking and DNA repair genes and metabolism traits

\begin{tabular}{|c|c|c|c|c|}
\hline Smoking status & Genotype & $N$ & $\begin{array}{l}\text { Crude SCE frequency } \\
\left(95 \% \mathrm{CI}^{\mathrm{a}}\right)\end{array}$ & $\begin{array}{l}\text { Adjusted SCE } \\
\text { frequency }^{\mathrm{b}}(95 \% \mathrm{CI})\end{array}$ \\
\hline \multicolumn{5}{|l|}{ XRCC1 (codon 399) } \\
\hline \multirow[t]{2}{*}{ Non-smoker } & Arg/Arg & 16 & $7.4(6.8-8.1)$ & $7.5(6.9-8.0)$ \\
\hline & $\mathrm{Arg} / \mathrm{Gln}+\mathrm{Gln} / \mathrm{Gln}$ & 15 & $6.9(6.3-7.4)$ & $6.8(6.3-7.4)$ \\
\hline \multirow[t]{2}{*}{ Cigarette per day $<10$} & Arg/Arg & 2 & $8.4(7.8-9.3)$ & $8.5(7.2-9.7)$ \\
\hline & $\mathrm{Arg} / \mathrm{Gln}+\mathrm{Gln} / \mathrm{Gln}$ & 4 & $8.1(4.3-11.5)$ & $7.9(6.8-9.4)$ \\
\hline \multirow[t]{3}{*}{ Cigarette per day $\geq 10$} & Arg/Arg & 14 & $7.9(7.4-8.4)$ & $7.9(7.4-8.6)^{\mathrm{c}}$ \\
\hline & $\mathrm{Arg} / \mathrm{Gln}+\mathrm{Gln} / \mathrm{Gln}$ & 10 & $9.1(8.3-9.6)$ & $9.0(8.3-9.6)$ \\
\hline & & & $P=0.0003^{\mathrm{d}}$ & $P=0.02^{\mathrm{e}}$ \\
\hline \multicolumn{5}{|l|}{ GSTM1 } \\
\hline \multirow[t]{2}{*}{ Non-smoker } & Non-null & 12 & $6.9(6.3-7.4)$ & $6.8(6.2-7.5)$ \\
\hline & Null & 19 & $7.4(6.8-8.0)$ & $7.3(6.8-7.9)$ \\
\hline \multirow[t]{2}{*}{ Cigarette per day $<10$} & Non-null & 3 & $7.9(4.3-11.5)$ & $7.8(6.5-9.2)$ \\
\hline & Null & 3 & $8.6(7.8-9.3)$ & $8.6(7.3-10.0)$ \\
\hline \multirow[t]{3}{*}{ Cigarette per day $\geq 10$} & Non-null & 12 & $8.2(7.6-8.6)$ & $8.3(7.6-9.0)$ \\
\hline & Null & 12 & $8.6(7.8-9.3)$ & $8.6(7.9-9.2)$ \\
\hline & & & $P=0.0032^{\mathrm{d}}$ & \\
\hline \multicolumn{5}{|l|}{ mEH (exon 3) } \\
\hline \multirow[t]{2}{*}{ Non-smoker } & $1-1$ & 10 & $6.8(6.3-7.3)$ & $6.8(6.0-7.5)$ \\
\hline & $1-2 / 2-2$ & 21 & $7.3(6.7-7.9)$ & $7.3(6.8-7.8)$ \\
\hline \multirow[t]{2}{*}{ Cigarette per day $<10$} & $1-1$ & 3 & $7.8(4.6-10.9)$ & $7.9(6.6-9.3)$ \\
\hline & $1-2 / 2-2$ & 3 & $8.7(7.4-10.0)$ & $8.5(7.2-9.8)$ \\
\hline \multirow[t]{3}{*}{ Cigarette per day $\geq 10$} & $1-1$ & 13 & $8.4(7.6-9.0)$ & $8.4(7.8-9.0)$ \\
\hline & $1-2 / 2-2$ & 11 & $8.3(7.5-9.1)$ & $8.4(7.7-9.1)$ \\
\hline & & & $P=0.0035^{\mathrm{d}}$ & \\
\hline \multicolumn{5}{|l|}{ mEH (exon 4) } \\
\hline \multirow[t]{2}{*}{ Non-smoker } & $1-2 / 2-2$ & 7 & $6.6(5.2-8.3)$ & $6.7(5.8-7.6)$ \\
\hline & $1-1$ & 24 & $7.4(6.9-7.7)$ & $7.2(6.8-7.7$ \\
\hline \multirow[t]{2}{*}{ Cigarette per day $<10$} & $1-2 / 2-2$ & 1 & $8.1(-)$ & 8.1 \\
\hline & $1-1$ & 5 & $8.9(6.8-9.4)$ & $9.2(6.9-11.5)$ \\
\hline \multirow[t]{3}{*}{ Cigarette per day $\geq 10$} & $1-2 / 2-2$ & 5 & $8.5(8.0-9.0)$ & $8.3(7.2-9.4)$ \\
\hline & $1-1$ & 19 & $8.0(6.4-9.5)$ & $8.5(8.0-9.0)$ \\
\hline & & & $P=0.003^{\mathrm{d}}$ & \\
\hline
\end{tabular}

\footnotetext{
${ }^{\mathrm{a}} \mathrm{CI}$ : confidence interval.

${ }^{\mathrm{b}}$ Adjusted SCE frequency adjusted for age, XRCC1, GSTM1, mEH (exon 3), and mEH (exon 4).

${ }^{\mathrm{c}} P<0.05$, between XRCC1 Arg/Gln + Gln/Gln and Arg/Arg.

${ }^{\mathrm{d}} P$-value based on ANOVA test.

e Test for interaction between smoking status and XRCC1 polymorphisms.
}

regression lines obtained by cigarette smoked per day and genotypes GSTM1 and mEH exons 3 and 4 did not indicate a significant difference.

\section{Discussion}

We investigated the relationship between polymorphisms of DNA repair gene and metabolic traits, and cigarette smoke-induced DNA damage. The results revealed that DNA repair gene XRCC1 codon 399 modulated the relationship between cigarette smoking and SCE frequency.

The prevalence of genetic polymorphisms of XRCC1 Gln399 allele (27.8\%) in the current study was consistent with the study conducted by Lunn et al. $(26.0 \%)$ in a Taiwanese population [26]. The prevalence of GSTM1 null genotype (55.7\%) was 
Table 3

Effect of XRCC1, glutathione $S$-transferase M1, microsomal epoxide hydrolase exons 3 and 4 on the relationship between sister chromatid exchange and cigarette smoked per day

\begin{tabular}{|c|c|c|c|}
\hline & $\begin{array}{l}\text { Intercept } \\
\text { (SCE) }\end{array}$ & $\begin{array}{l}\text { Slope (SCE per } \\
\text { cigarette per day) }\end{array}$ & $\begin{array}{l}\text { Slope difference } \\
(P)^{\mathrm{a}}\end{array}$ \\
\hline \multicolumn{4}{|l|}{ XRCC1 } \\
\hline Arg/Arg & 6.86 & 0.022 & \\
\hline $\begin{array}{l}\mathrm{Arg} / \mathrm{Gln} \\
\quad+\mathrm{G} \ln / \mathrm{Gln}\end{array}$ & 9.17 & 0.11 & 0.02 \\
\hline \multicolumn{4}{|l|}{ GSTM1 } \\
\hline Non-null & 8.89 & 0.76 & \\
\hline Null & 8.93 & 0.08 & 0.4333 \\
\hline \multicolumn{4}{|l|}{ mEH exon 3} \\
\hline $1-1$ & 8.93 & 0.086 & \\
\hline $1-2 / 2-2$ & 7.31 & 0.06 & 0.4530 \\
\hline \multicolumn{4}{|l|}{ mEH exon 4} \\
\hline $1-1$ & 9.23 & 0.0737 & \\
\hline $1-2 / 2-2$ & 6.07 & 0.023 & 0.4567 \\
\hline
\end{tabular}

\footnotetext{
${ }^{a}$ Comparison with the corresponding genotype.
}

similar to a previous study conducted in Taiwanese descendants $(60.6 \%)$ [27]. The prevalence of $\mathrm{mEH}$ exon $3(37.7 \%)$ and exon $4(11.4 \%)$ alleles were also close to a previous study with Asian control subjects (mEH exon 3: 36.7\%, $\mathrm{mEH}$ exon 4: 9.3\%) [28].
The results of our study support previous epidemiological studies that XRCC1 may play a role in cigarette smoking-induced cancers. XRCC1 protein participates in the BER pathway with DNA ligase III, PARP and POL $\beta$ (DNA polymerase $\beta$ ) [20]. It is biologically plausible that the amino acid substitution at codon 399 may alter the enzyme complex structure leading to a deficiency of binding between PARP and XRCC1 protein which may cause deficiencies in the DNA repair capacity [20]. According to a study by Sturgis et al. [23] on head and neck cancers, there are increased risks for the XRCC1 Gln399 homozygous variants compared with those with one or more copies of the common allele. The odds ratio of head and neck cancers between patients and control subjects was more prominent in those who were current smokers. A positive association of XRCC1 Gln399 allele with adenocarcinoma of lung and gastric cancer have also been reported [5,29]. However, Stern et al. [4] reported that the possible reduction in bladder cancer risk among subjects with XRCC1 Gln399. A recent study suggested that bladder cancer could be modulated by XRCC3, but similar impacts were not observed for XRCC1 and XPD [30]. Butkiewisz et al. suggested that the polymorphisms in XPD repair gene,

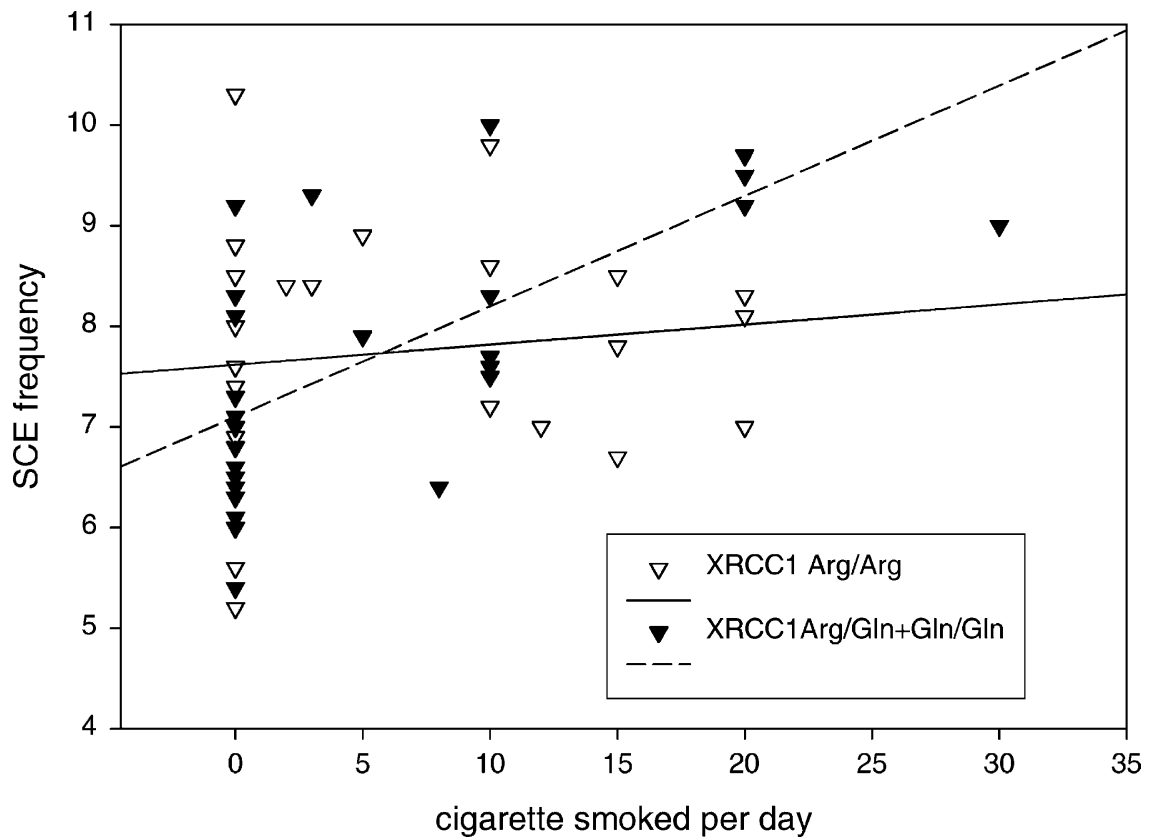

Fig. 1. SCE frequency in study subjects with XRCC1 Arg/Arg and XRCC1 Arg/Gln + Gln/Gln genotypes. 
which involved in nucleotide excision pathway, may be related to the risk of lung cancer [31]. It appears that the association between DNA repair genotypes and smoking-related cancers were less consistent. Recently, Duell et al. [7] revealed that individuals with XRCC1 Gln399 allele might be at greater risk for tobacco-related DNA damage, which was consistent with our findings. Cigarette smoke contains not only potent carcinogens, such as benzo(a)pyrene and 4-methylnitrosamino-1- (3-pyridyl)-1-butanone (NNK), but also a large amount of reactive oxygen species (ROS). Studies have shown that bulky adducts induced by specific chemical carcinogens were repaired through nucleotide excision repair (NER) pathway [32], whereas, single strand breaks and oxidative damage were repaired by base excision repair (BER) pathways [21]. Thus, it seems plausible that DNA damage caused by ROS in cigarette smoke may be repaired by XRCC1. Furthermore, the increase of 8-hydroxydeoxyguanine in DNA may be repaired through the BER pathway $[33,34]$. XRCC1 gene polymorphism also appeared to be associated with reduced repair of NNK-induced genetic damage [35].

Earlier studies have indicated that the GSTM1 null genotype is associated with lung cancer, and that the risk of lung cancer increased with the amount of cigarette smoking [36,37]. Other investigators also found that cigarette-related DNA adducts and chromosome breakages were higher in GSTM1 null genotype individuals than GSTM1 non-null individuals among smokers [38,39]. In this study, subjects with GSTM1 null genotype had higher mean SCE frequency than subjects with GSTM1 non-null genotype particularly in smokers who smoked less than 10 cigarettes per day, although the association did not reach a statistical significance because of small sample size. Similar finding was also observed in a earlier study which revealed that the effect of GSTM1 null type on lung cancer was more prominent in those with low dose of cigarette smoking [40]. It is thus conceivable that deficiency in GST activity may modulate susceptibility to smoking-induced cancers.

Effects of mEH exons 3 and 4 were not observed on cigarette-related SCE frequency in this study. $\mathrm{mEH}$ metabolizes polycyclic aromatic hydrocarbons and carcinogens found in cigarette smoke [13]. Polymorphisms in exons 3 and 4 of the $\mathrm{mEH}$ gene have been found to alter $\mathrm{mEH}$ activity [14]. However, the relationships between $\mathrm{mEH}$ genotype and lung cancer risk has been inconsistent. Wu et al. reported that the $\mathrm{mEH}$ exon 4 polymorphisms may be associated with an increased lung cancer risk [41], and Benhamou et al. found significant association between $\mathrm{mEH}$ activity and lung cancer [17]. However, Zhou et al. suggested that there was no relationship between $\mathrm{mEH}$ genotypes and lung cancer [42]. Moreover, Smith and Harrison [16] suggested an increased risk of smoking-induced emphysema for those with low activity of $\mathrm{mEH}$ exon 3 . Another study indicated that the polymorphism of $\mathrm{mEH}$ is not associated with susceptibility to emphysema in Japanese population [43]. Further study is needed to clarify the role of $\mathrm{mEH}$ in smoking-related carcinogenesis.

Other metabolic traits including CYP1A1 and CYP2D6 may also modulate the SCE frequency caused by cigarette smoke. Because these metabolite traits usually catalyze bulky chemicals, which are less relevant to XRCC1, and their prevalence is relatively low, they were not considered in the current analysis.

Although based on relatively small numbers, our results suggest that XRCC1 polymorphisms may play an important role in cigarette smoke-induced DNA damage. Our study also supports previous epidemiological studies that XRCC1 may play a role in cigarette smoking-induced cancers. This study was supported by Grants NSC 86-2621-B-002-010, NSC 87-2621-B-002-010, and NSC 89-2314-B-002-389 from the National Science Council, Taiwan.

\section{References}

[1] Smoking and Health: A Report of the Surgeon General US DHEW, 1979

[2] H. Bartsch, U. Nair, A. Risch, M. Rojas, H. Wikman, K. Alexandrov, Genetic polymorphism of CYP genes, alone or in combination, as a risk modifier of tobacco-related cancers, Cancer Epidemiol. Biomarkers Prev. 9 (2000) 3-28.

[3] L.L. Marchand, L. Sivaraman, L. Pierce, A. Seifried, A. Lum, L.R. Wilkens, A.F. Lau, Associations of CYP1A1, GSTM1, and CYP2E1 polymorphisms with lung cancer suggest cell type specificities to tobacco carcinogens, Cancer Res. 58 (1998) 4858-4863.

[4] M.C. Stern, D.M. Umbach, C.H.v. Gils, M.R. Lunn, J.A. Taylor, DNA repair gene XRCC1 polymorphisms, smoking, and bladder cancer risk, Cancer Epidemiol. Biomarkers Prev. 10 (2001) 125-131.

[5] K.K. Divine, F.D. Gilliland, R.E. Crowell, C.A. Stidley, T.J. Bocklage, D.L. Cook, S.A. Belinsky, The XRCC1 glutamine 
399 allele is a risk factor for adenocarcinoma of the lung, Mutat. Res. 461 (2001) 273-278.

[6] T.J. Cheng, D.C. Christiani, X. Xu, J.C. Wain, J.K. Wiencke, K.T. Kelsey, GST mu, diet and smoking as determinants of sister chromatid exchanges in lymphocytes, Cancer Epidemiol. Biomarkers Prev. 4 (1995) 535-542.

[7] E.J. Duell, J.K. Wiencke, T.J. Cheng, A. Varkonyi, Z.F. Zuo, T.D.S. Ashok, E.J. Mark, J.C. Wain, D.C. Christiani, K.T. Kelsey, Polymorphisms in the DNA repair gene XRCC1 and ERCC2 and biomarkers of DNA damage in human blood mononuclear cell, Carcinogenesis 21 (2000) 956-971.

[8] K. Nakachi, K. Iami, S.I. Hayashi, K. Kawajiri, Polymorphism of the CYP1A1 and glutathione $S$-transferase genes associated with susceptibility to lung cancer in relation to cigarette dose in a Japanese population, Cancer Res. 53 (1993) 2994-2999.

[9] C. Bouchardy, S. Benhamou, P. Dayer, The effect of tobacco on lung cancer depends on CYP2D6 activity, Cancer Res. 56 (1996) 251-253.

[10] L.L. Marchand, L. Savaraman, L. Pierce, A. Seifreid, A. Lun, L.R. Wilkens, A.F. Lau, Association of CYP1A1, GSTM1, and CYP2E1 polymorphisms with lung cancer suggest cell type specificities to tobacco carcinogens, Cancer Res. 58 (1998) 4858-4863.

[11] A. Lafrente, F. Pujol, P. Carretero, J.P. Villa, A. Cuchi, Human glutathione $S$-transferase mu deficiency as a marker for the susceptibility to bladder and larynx cancer among smokers, Cancer Lett. 68 (1993) 49-54.

[12] M. Rojas, I. Cascorbi, K. Alexandrov, E. Kriek, G. Auburtin, L. Mayer, A. Kopp-Schneider, I. Roots, H. Bartsch, Modulation of benzo(a)pyrene diolepoxide-DNA adduct levels in human white blood cells by CYP1A1, GSTM1 and GSTT1 polymorphism, Carcinogenesis 21 (2000) 35-41.

[13] A.J. Fregland, C.J. Omiecinski, Epoxide hydrolase: biochemistry and molecular biology, Chem. Biol. Interact. 129 (2000) 41-59.

[14] C. Hassett, L. Aicher, J.S. Sidhu, C.J. Omiecinski, Human mircosomal epoxide hydrolase: genetic polymorphism and functional expression in vitro of amino acid variants, Hum. Mol. Genet. 3 (1994) 421-428.

[15] C. Hassett, K.B. Robinson, N.B. Beck, C.J. Omiecinski, The human microsomal epoxide hydrolase gene (EPHX1): complete nucleotide sequence and structural characterization, Genomics 23 (1994) 433-442.

[16] C.D. Smith, D.J. Harrison, Association between polymorphism in gene for microsomal epoxide hydrolase and susceptibility to emphysema, Lancet 350 (1997) 630-633.

[17] S. Benhamou, M. Reinikainen, C. Bouchardy, P. Dayer, A. Hirvonen, Association between lung cancer and microsomal epoxide hydrolase genotypes, Cancer Res. 58 (1998) 52915293.

[18] H.W. Mohrenweiser, I.M. Jones, Variation in DNA repair is a factor in cancer susceptibility: a paradigm for the promised and perils of individual and population risk estimation? Mutat. Res. 400 (1998) 15-24.

[19] M.Z. Zdzienicka, G.P.v.d. Schans, A.T. Natarajan, L.H. Thompson, I. Nueteboom, J.W.I.M. Simons, A Chinese hamster ovary cell mutant (EM-C11) with sensitivity to simple alkylating agents and a very high level of sister chromatid exchanges, Mutagenesis 7 (1992) 265-269.

[20] M.R. Shan, I.M. Jones, H. Morenweiser, Non-conservative amino acid substitution variants exist at polymorphic frequency in DNA repair gene in healthy humans, Cancer Res. 58 (1998) 604-608.

[21] A. Marintchev, A. Robertson, E.K. Dimitriadis, R. Prasad, S.H. Wilson, G.P. Mullen, Domain specific interaction in the XRCC1-DNA polymerase $\beta$ complex, Nucleic Acids Res. 28 (2000) 2049-2059.

[22] M.R. Shan, M.Z. Zdzienicka, H.L.H. Morenweiser, M.P. Thompson, The mutations in hamster single-strand break repair gene XRCC1 causing defective DNA repair, Nucleic Acids Res. 26 (1998) 1032-1037.

[23] E.M. Sturgis, E.J. Castillo, L. Li, R. Zheng, S.A. Eicher, G.L. Clayman, S.S. Strom, M.R. Spitz, Q. Wei, Polymorphisms of DNA repair gene XRCC1 in squamous cell carcinoma of the head and the neck, Carcinogenesis 20 (1999) 2125-2129.

[24] T.J. Cheng, S.J. Hwang, H.W. Kuo, J.C. Luo, M.J.W. Chang, Exposure to epichlorohydrin and dimethylformamide, glutathione $S$-tranferase and sister chromatid exchange frequencies in peripheral lymphocytes, Arch Toxicol. 73 (1999) 282-287.

[25] P. Perry, S. Wolff, New Giemsa method for the difference staining of sister chromatids, Nature (London) 251 (1974) $156-158$.

[26] R.M. Lunn, R.G. Langlois, L.L. Hsieh, C.T. Thompson, D.A. Bell, XRCC1 polymorphisms: effects on alfatoxin B1-DNA adducts and glycophorin A variant frequency, Cancer Res. 59 (1999) 2557-2561.

[27] C.Y. Huang, K.L. Huang, T.J. Cheng, J.D. Wang, L.L. Hsieh, The GSTT1 and CYP2E1 genotypes are possible factors causing vinyl chloride induced abnormal liver function, Arch. Toxicol. 71 (1997) 482-488.

[28] V. Cortessis, K. Siegmund, Q. Chen, N. Zhou, A. Diep, H. Frankl, E. Lee, Q.S. Zhu, R. Halie, D. Levy, A case-control study of microsomal epoxide hydrolase, smoking, meat consumption, glutathione $S$-transferase M3, and risk of colorectal adenomas, Cancer Res. 61 (2001) 2381-2385.

[29] H. Shen, Y. Xu, Y. Qian, R. Yu, Y. Qin, L. Zhou, X. Wang, M.R. Spitz, Q. Wei, Polymorphisms of the DNA repair gene $\mathrm{XRCC} 1$ and risk of gastric cancer in a Chinese population, Int. J. Cancer 88 (2000) 601-606.

[30] G. Matullo, S. Guarrera, S. Carturan, M. Peluso, C. Malvaveille, L. Davico, A. Plazza, P. Vineis, DNA repair gene polymorphisms, bulky DNA adducts in white blood cells and bladder cancer in a case-control study, Int. J. Cancer 92 (2001) 562-567.

[31] D. Butkiewicz, M. Rusin, L. Enewold, P.G. Shields, M. Chorazy, C.C. Harris, Genetic polymorphisms in DNA repair genes and risk of lung, Carcinogenesis 22 (2001) 593-597.

[32] A.R. Lehmann, Nucleotide excision repair and the link with transcription, Trends Biochem. Sci. 20 (1995) 402-405.

[33] A.B. Weitberg, D. Corvese, Oxygen radicals potentiate the genetic toxicity of tobacco-specific nitrosamines, Clin. Genet. 43 (1993) 88-91.

[34] B. Salles, U. Sattler, C. Bozzato, P. Calsou, Repair of oxidative DNA damage in vitro: a tool for screening antioxidative compounds, Food Chem. Toxicol. 37 (1999) 1009-1014. 
[35] S.Z. Abdel-Rahman, R.A. El-Zein, The Gln399 polymorphism in the DNA repair gene XRCC1 modulates the genotoxic response induced in human lymphocytes by the tobaccospecific nitrosamine NNK, Cancer Lett. 159 (2000) 63-71.

[36] M. Kihara, K. Noda, Lung cancer risk of GSTM1 null genotype is dependent on the extent of tobacco smoke exposure, Carcinogenesis 15 (1994) 415-418.

[37] J.G. Ford, Y. Li, M.M. O'Sullivan, R. Demopoulos, S. Garte, E. Taioli, P.W. Buandt-Rauf, Glutathione $S$-transferase M1 polymorphisms and lung cancer risk in African-Americans, Carcinogenesis 21 (2000) 1971-1975.

[38] S.A. Salama, S.Z. Abdel-Rahman, C.H. Sierra-Torres, E.A. Hamada, W.W. Au, Role of polymorphic GSTM1 and GSTT1 genotypes on NNK-induced genotoxicity, Pharmacogenetics 9 (1999) 735-743.

[39] R.W. Godschalk, J.W. Dallinga, H. Wikman, A. Risch, J.C. Kleinjans, H. Bartsch, F.J. Van Schooten, Modulations of DNA and protein adducts in smokers by genetic polymorphisms in GSTM1, GSTT1, NAT1 and NAT2, Pharmacogenetics 11 (2001) 389-398.
[40] S.J. London, A.K. Daly, J. Cooper, W.C. Navidi, C.L. Carpenter, J.R. Idle, Polymorphism of glutathione $S$-transferase $\mathrm{M} 1$ and lung cancer risk among African-Americans and Caucasians in Los Angeles Country, CA J. Natl. Cancer Inst. 87 (1995) 1246-1253.

[41] X. Wu, K. Gwyn, C.I. Amos, N. Makan, W.K. Hong, M.R. Spitz, The association of microsomal epoxide hydrolase polymorphisms and lung cancer risk in African-Americans and Mexican-Americans, Carcinogenesis 22 (2001) 923928.

[42] C. Zhou, S.W. Thurston, G. Liu, L.L. Xu, D.P. Miller, J.C. Wain, T.J. Lynch, L. Su, D.C. Christiani, The interaction between microsomal epoxide hydrolase polymorphisms and cumulative cigarette smoking in different histological subtypes of lung cancer, Cancer Epidemiol. Biomarkers Prev. 10 (2001) 461-466.

[43] K. Takeyabu, E. Yamaguchi, I. Suzuki, M. Nishimura, N. Hizawa, Y. Kamakami, Gene polymorphism for microsomal epoxide hydrolase and susceptibility to emphysema in a Japanese population, Eur. Respir. J. 15 (2000) 891-894. 